\title{
Cows and guns. Cattle-related conflict and armed violence in Fizi and Itombwe, eastern DR Congo*
}

\author{
JUDITH VERWEIJEN \\ Nordic Africa Institute and Ghent University, Universiteitstraat 8, \\ B-gooo Ghent, Belgium
}

Email: judith.verweijen@ugent.be

and

Justine Brabant

Independent researcher

Email: justine.brabant@gmail.com

\section{A B S T R A C T}

This paper analyses the role of cattle in the entwined dynamics of conflict and violence in the Fizi and Itombwe region of South Kivu province, in the eastern Democratic Republic of the Congo. On the one hand, agropastoral conflict intensifies armed mobilisation, allowing armed groups to draw upon particular conflict narratives that generate popular and elite support. It also creates incentives for armed actors to engage in cattle-looting, or the defence against it, for both symbolic and material reasons. On the other hand, the presence of armed forces and the use of violence profoundly shape agropastoral conflicts. Importantly, they change the perceived stakes of these conflicts, and hamper their resolution. By showing that the relations between cattle-related conflict and armed activity are indirect, complex and mutual, the paper refines both theories on agropastoral conflict and those highlighting the role of local conflicts in fuelling violence in the eastern Congo.

* This article partly draws upon research funded by the Swedish Research Council [grant number 348-2013-145] and the Life \& Peace Institute. 
In November 2011 , the Democratic Republic of the Congo (henceforth the Congo) held its second presidential and parliamentary elections after the adoption of a peace accord in 2003. However, in the Itombwe area of the Hauts Plateaux mountains, located at the intersection of the territories of Mwenga, Fizi and Uvira in South Kivu province (see Figure 1), citizens were not able to vote. Weeks of ongoing tit-for-tat killings between members of the Babembe and Banyamulenge communities impeded the arrival of the voting material, which had to be carried on foot through the impenetrable Itombwe forest. While the reasons for this episode of violence are multiple, one of the factors fostering antagonism between the two groups were the repeated massive lootings of the Banyamulenge's cattle by the Bembe 'Mai-Mai' (a generic name for small-scale armed groups drawing on discourses of autochthony and self-defence) of self-proclaimed 'General' Aoci in the Mibunda area. The Babembe, for their part, resented the occasional destruction of their fields by the Banyamulenge's cattle, and deeply distrusted the Banyamulenge rebel movement Forces Républicaines Fédéralistes (FRF) believed to protect this community's cows. This episode of violence thus points to the complex interplay between cattle-related tensions, armed group activity, and inter-community conflicts, which is an important driver of instability in Fizi and the Itombwe part of Mwenga.

Drawing on over a year of intermittent ethnographic fieldwork conducted between 2010 and 2014 by each author individually, this article analyses the relations between agropastoral conflict and armed activity in one sub-area of the eastern Congo. How do the presence of state and non-state armed forces and the eruption of violence in past and present change the dynamics of agropastoral conflicts? And in what ways do disputes between cattle-keepers and farmers shape the social and discursive practices of armed actors? By analysing these questions, the article aims to contribute to the cross-fertilisation of two bodies of literature that have hitherto often remained separate, namely, works studying pastoralism and agropastoral conflict on the one hand, and those focusing on the microdynamics of violent conflict, in particular armed group activity, on the other. In this manner, we intend to refine theories highlighting the role of local conflicts in the ongoing violence in the eastern Congo, which are part of a wider 'local turn' in peacebuilding practice and analysis (Hughes et al. 2015).

In the parts of Fizi and Itombwe studied herein, agropastoral conflicts, which often overlap with wider inter-community tensions, intersect with 


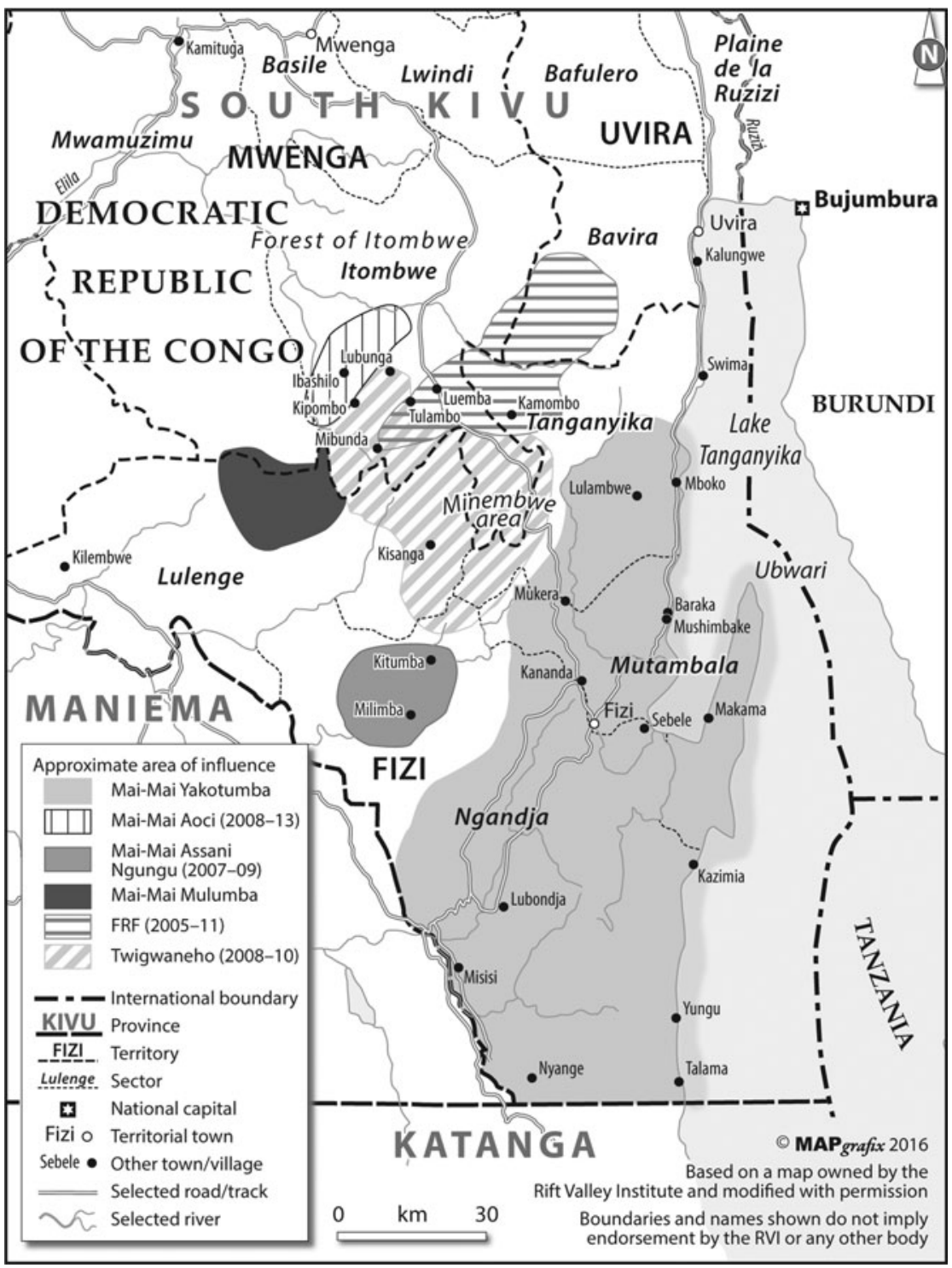

Figure 1 Fizi and Itombwe, showing approximate areas of armed group influence.

armed actor activity, notably cattle-looting and the defence against it. This intersection transforms the nature of both armed mobilisation and agropastoral conflict. On the one hand, agropastoral conflicts intensify the mobilisation of armed groups, as they allow the latter to draw 
upon particular conflict narratives that generate popular and elite support. Furthermore, these conflicts shape the practices of both state and non-state armed actors, incentivising them to engage in either cattle-looting or its prevention, for both symbolic and material reasons. On the other hand, the presence of armed forces and the use of violence in past and present profoundly influence agropastoral conflicts. Importantly, they change the perceived stakes of these conflicts by adding a layer of (existential) threat, and erode mechanisms to achieve their non-violent resolution. Our analysis thus demonstrates that there is no linear causal relationship between local conflicts and violence. Rather, the mechanisms linking these two phenomena pass through various intermediary stages, which are crucially shaped by the presence and practices of both armed groups and the national armed forces, in particular the latter's tendency to engage in particularistic protection arrangements, which undermines their perceived neutrality. Armed group presence, in turn, is not a direct outcome of local conflicts either, as armed mobilisation requires sustained financial and organisational inputs that are often provided by political elites who are not always a direct party to agropastoral conflicts. Furthermore, we show that the links between local conflicts and armed mobilisation and violence are not unidirectional, but mutual: the presence of armed forces and the occurrence of violence crucially alter the nature of conflict.

The paper is organised as follows. After a brief discussion of the literature on violent agropastoral conflict, we turn to the context of Fizi and Itombwe, describing the ways in which cattle-related disputes in this region have historically become intertwined with inter-community conflict and warfare. Subsequently, we analyse how the legacies of the Congo Wars have transformed conflicts related to transhumance, highlighting the importance of ethnic framings, autochthony discourses and armed group presence, and how these phenomena hamper conflict regulation. The next two sections discuss armed group activity, focusing on how it induces both the multiplication and the militarisation of cattlerelated conflicts and changes their stakes. Subsequently, we examine the role of the Congolese national army, illustrating how popular distrust towards the army and its tendency to engage in protection practices are crucial factors in linking conflicts to armed group activity. The concluding section details the implications of our findings for the theorisation of the links between agropastoral conflicts and violence and of the role of local conflicts in armed mobilisation and violence in the eastern Congo more generally. 
THEORISING THE RELATIONS BETWEEN AGROPASTORAL

C ONFLICT AND VIOLENCE

Conflicts between what we will call herein - despite the term's problematic connotations ${ }^{1}$ - 'communities' depending predominantly on livestock keeping (herders/pastoralists) on the one hand, and those primarily engaged in crop farming (farmers/agriculturalists) on the other, abound in Sub-Saharan Africa. While there is an extensive literature on the drivers of these conflicts, there has been less systematic study of the questions why, when and how these conflicts contribute to violence. One reason is that many studies fail to make a sharp conceptual distinction between conflicts and violence and do not always differentiate between different types of violence, for instance communal, interpersonal and armed group violence (Hussein et al. 1999). Moreover, only few studies examine the microdynamics of violence, which requires the comprehensive study of individual instances of violence and the processes leading up to them, while distinguishing between broader underlying causes and immediate triggers (Collins 2008). In sum, much of the literature fails to disaggregate the dynamics of conflict from the dynamics of violence. However, as argued by Brubaker \& Laitin (1998: 426): 'violence is not a quantitative degree of conflict, but a qualitative form of conflict, with its own dynamics'.

The analytical imprecisions regarding violence and its drivers are clear when looking at the explanatory factors that are commonly cited in the literature on violent agropastoral conflict. These fall into four broad categories: (1) changing patterns of resource use due to environmental and demographic factors; (2) 'culture' and identity-related factors; (3) political and institutional factors, often related to mechanisms of dispute resolution and elite behaviour; and (4) the proliferation of small arms. Not only is there no consensus on the relative causal weight of each of these factors, the causal pathways by which they lead up to violence often remain unspecified (Eaton 2008). A clear example are studies highlighting environmental factors, like drought, ecological degradation and demographic increase, which are posited to lead to growing competition for resources induced by 'scarcity' (e.g. Markakis 1997; cf. Homer-Dixon 1999). Yet while it is generally recognised that environmental degradation and growing pressures on land might intensify conflicts, many scholars have pointed to the analytical inadequacies of the notion of 'resource scarcity', and emphasised that the link with violence is not self-evident (Hagmann 2005; Bogale \& Korf 2007). 
Similar concerns have been raised in relation to explanations focusing on 'culture' and identities, in particular those considering forms of violence, like violent cattle-raiding, a 'normal' feature of particular pastoralist communities' life-worlds and regulatory mechanisms (Hendrickson et al. 1996; Abbink 1998). Yet, few studies focusing on customs and forms of social identification are primordialist or determinist in nature. Instead, the majority ascribe hostile mutual representations held by pastoralists and farmers to a complex interplay of on the one hand, discourses of ethnicity, and on the other hand, political and socio-economic processes, like the negative stereotyping of pastoralists in state discourse (e.g. Umar 1997) or intra-group competition leading to 'ethnic outbidding' (Breusers et al. 1998). Some of these studies have also drawn attention to the importance of discourses of autochthony, which frame (semi)nomadic pastoralists as 'strangers' or 'outsiders', while identifying farmers as 'natives/indigenous' or 'sons/ daughters of the soil' (Tonah 2003; Pelican 2009). Similar to discourses of ethnicity (Brubaker \& Laitin 1998), the role of notions of autochthony in sparking violence, however, is by no means straightforward, and tends to be assumed rather than proven (Verweijen 2015a).

A third cluster of explanations for violent herder-farmer conflicts highlights political and institutional factors, including the erosion of established mechanisms of conflict resolution and the cooperative management of natural resources. The effectiveness of state institutions, such as formal courts and state administrators providing litigation, may be undermined when there is reduced trust related to perceptions of bias (Harshbarger 1995) or corruption (Benjaminsen et al. 2009). Customary authority often erodes as a result of factors like diminishing cohesion among elders; the proliferation of arms-bearing youth and changes in the political system, such as decentralisation processes (Mwaura \& Schmeidl 2002; Beyene 2009). Again, the literature does not always specify how and why the erosion of established conflict resolution mechanisms leads to violence; not being able to resolve a conflict is one thing, inflicting physical harm, or supporting others to do so, is quite another.

While the causal pathways toward violence often remain unspecified, one sub-strand of the politically oriented literature on violence and agropastoral conflict does conceptualise causal mechanisms more clearly. This literature points to the agency of political and military elites, and analyses how it is affected by political processes such as elections, democratisation and decentralisation (Hagmann \& Mulugeta 2008; Greiner 2013). Most of these studies focus on areas where violent 
cattle-raiding has assumed significant proportions, often as part of broader economies of violence characterised by rampant banditry (Agade Mkutu 2008). The emergence of such violent economies is generally ascribed to multiple interacting processes, including growing opportunities for the commercialisation of looted cattle (Hendrickson et al. 1996; Fleisher 2002), manipulation by politicians (Greiner 2013), and the rise of politico-military entrepreneurs, including 'cattle warlords/racketeers', who engage 'guns-for-hire' to carry out cattle raids (Krätli \& Swift 1999; Odhiambo 2004). The literature focusing on violent cattle-raiding commonly also highlights a fourth factor identified as contributing to violence, namely, the proliferation of small arms, which is said to create new conflicts and to transform social relations, in particular between youth and elders (Mirzeler \& Young 2000; Hundie 2010). It remains contested, however, to what extent the proliferation of arms contributes directly to violence. Some have argued that the effects are mostly indirect and are usually only manifested in interaction with other factors (e.g. Eaton 2008).

While the body of literature on violent cattle-raiding discussed above offers quite specific explanations for violence, only a small part focuses on agropastoral conflict. The reason is that in most contexts, cattlelooting occurs primarily among groups of pastoralists, rather than between cattle-herders and farmers or agropastoralists. An exception is Beyene's work on eastern Ethiopia, in which he concludes that 'livestock raids are the principal cause of the failure of informal agreements to prevent conflict between pastoralists and agropastoralists' (Beyene 2009: 216). This observation also draws attention to the inverse of the question of how conflicts influence violence, namely, that of the effects of violence on conflicts. Violence is generally recognised to lead to breakdowns of regulatory mechanisms between and among pastoralists and agriculturalists, like friendship pacts, fines and compensation systems. Additionally, it fosters changing patterns of leadership, as it displaces the authority of elders to the benefit of local (politico-military) strongmen (more rarely women) (Agade Mkutu 2008). Furthermore, violent forms of banditry, including cattle-raiding, often become new sources of conflict, which may then come to feed into new rounds of violence (Krätli \& Swift 1999). The resulting insecurity may also foster the development of vigilantes, which in some cases are relatively effective mechanisms for coping with cattle theft (Abrahams 1987). In other contexts, however, vigilantes may create yet more problems, as they start engaging in cattle-looting and other forms of banditry, or collaborate with deeply distrusted government forces. 
Moreover, vigilantes are sometimes linked to identity-based communities that are in conflict with other such communities, therefore ending up exacerbating communal conflict (Agade Mkutu 2008).

The complex interplay between communal conflict and acts of violence, whether enacted by bandits or armed groups, receives growing attention in the literature on violence and (agro)pastoralist conflict. For instance, Eaton (2008) analyses how mundane incidents like 'seemingly insignificant theft' (2008: 89) may, through mutually hostile (ethnic) framings, set in motion a dynamic of tit-for-tat killings that spirals out of control. In a similar vein, Fleisher (2002) detects an interaction between individualised, commercialised cattle-raiding and warfare between clans, arguing that 'clan warfare not only serves to legitimise raids on the enemy's cattle herds so long as the fighting rages, but also fosters and sustains an atmosphere of inter-clan enmity that provides support for cattle-raiding ... even after war-time hostilities have ended'. This renders clan warfare 'both a cause and an effect' of commercialised raiding (Fleisher 2002: 131-2).

In relation to Fizi and Itombwe, we observe a similar complex interplay between cattle-looting by Mai-Mai groups and inter-communal conflicts between cattle-keepers and farmers. Thus, the analysis presented in this paper draws and further elaborates upon the line of enquiry set out by Eaton and Fleisher, who analyse the microdynamics of the intersections between different types of conflicts and different types of violence in a disaggregated manner. As such, it presents a fine-grained understanding of the processes and factors driving certain forms of violence in the eastern Congo.

\section{CATTLE AND WAR IN FIZI AND ITOMBWE}

Each year, during the dry season, which lasts from approximately June till September, tensions in Fizi and Itombwe rise. As cattle start their descent from the Hauts Plateaux to greener pastures in either Lulenge or Ngandja (see Figure 1), fears grow among cultivators that their fields will be trampled upon. At the same time, cattle-keepers worry about their cattle being stolen by some of the armed groups generically called 'Mai-Mai'. The resulting tensions are not purely the product of fears for material damage. Due to a long history of inter-community conflicts and episodes of violence, which have become entwined with cattlerelated conflict, transhumance and cattle-looting have pronounced 
identity-related and symbolic dimensions, which shape the ways in which these practices are framed and experienced.

While several communities in Fizi and Itombwe have cattle, the group that most depends on it for their livelihood, and who are locally identified as 'pastoralists', are the Banyamulenge. The latter are a Tutsi group whose language is considered to be a variety of Kinyarwanda, hence who are Rwandophones (Kinyarwanda speakers). Migrating in the pre-colonial era with their cattle from present-day Rwanda and Burundi to what is now South Kivu (Depelchin 1974), the colonial authorities denied this group a chefferie agrandie (enlarged customary chiefdom) of their own. Consequently, they had to pay tribute to the customary chiefs (bami, singular mwami) from other communities and had no land of their own (Vlassenroot 2002). This unequal access to land and local authority would become an important source of frictions between the Banyamulenge, and neighbouring communities, notably the Babembe, Bafuliiru, Banyindu and Bavira.

In the life-world of the Banyamulenge, whose livelihood and wellbeing depend on cattle, cows are part of the same moral community as humans. This elevated status is reflected in a well-developed tradition of pastoral poetry and songs and expressions that praise cows, like ntaco kiruta inka (nothing exceeds the value of a cow) (President of cattleherders 2012 int.). Additionally, wealth, including the dowry (bridewealth), is generally conceptualised in terms of cows (Rukundwa 2006). While this is also the case for certain other communities in the area, in particular the Bafuliiru, other groups, such as the Babembe, have dowry customarily given in goats, which creates obstacles to intermarriage with Banyamulenge. Another general difference between communities primarily oriented towards agriculture and those focused on cattle is the conceptualisation of and value attached to land. Whereas the Banyamulenge see land primarily in terms of grazing grounds, for most agriculture-oriented communities, land has not only elevated economic significance, as the main source of livelihood, but also bears socio-cultural and symbolic value. Access to communally held land is a precondition for insertion into the community's social networks, and is therefore a crucial underpinning of social cohesion and identification, not least as it ties people into a reciprocal relationship with the mwami (customary chief) and the lubunga (council of elders). This relationship entails displaying loyalty, including by paying different types of tribute like itulo (customary contribution), in exchange for basic forms of social security and solidarity, for instance in times of disappointing harvests (cf. Van Acker 2005). According to Bembe customary authorities, 
the connection to the soil is also spiritual, as the spirits of the ancestors, in Swahili commonly called mizimu wa mababu, are believed to guard the land, thus ensuring the connection between previous and current generations and between the community and its land (Chief of Basimunyaka clan 2012 int.).

The nexus between land, social identification and political organisation was strongly reinforced by the colonisers' approach to local administration, in particular their reliance on customary chiefs representing territorially fixed ethnic communities as intermediaries, which fostered the territorialisation of ethnicity and the ethnicisation of local authority (Muchukiwa 2006). These entwined processes sowed the seeds for the rise of a discourse that portrayed communities without a chefferie and land of their own, like the Banyamulenge, as 'non-natives' or 'foreigners' who did not have the right to Congolese citizenship. This discourse became particularly salient when the Banyamulenge stepped up their efforts to be accorded a local administrative entity of their own in the period following the Congo's independence in 1960. Neighbouring communities experienced this activism as a threat to their lands and power, leading them to emphasise their status as autochthones or 'sons/ daughters of the soil' vs. the Banyamulenge as putative 'foreigners'. This natives vs. foreigners distinction often overlapped with a dichotomy between on the one hand, 'Tutsi' or 'Nilotic' groups, commonly portrayed as 'pastoralists', and on the other hand, 'Bantu' populations, perceived to depend primarily on agriculture (Jackson 2006). It is this overlay with the autochthony discourse and its profound politicisation, rather than differences in life-worlds stemming from divergent livelihood orientations per se, that has been a crucial driver of conflict between the Banyamulenge and other groups.

An important catalyst of the politicisation of autochthony discourses was the legacy of the Simba rebellion that swept the region a few years after the Congo's accession to independence. Inspired by the revolutionary figure of Pierre Mulele, the Simba rebels revolted against the ancien régime accused of complicity with colonial oppression and imperialism (Verhaegen 1966). Obtaining a number of quick military successes, the Simba were soon beaten back by an offensive of the Armée Nationale Congolaise (ANC), the Congolese army, which was launched at the end of 1964 with the help of mercenaries and foreign military assistance. In response, the rebels withdrew into the Hauts Plateaux, where the cows of the Banyamulenge became their main source of supplies. This antagonised the Banyamulenge (Rukundwa 2006), prompting their self-defence group called Abagirye (derived from guerrier, 
French for 'warrior') to side with the ANC. The latter started to provide logistical support, including arms and ammunitions, to the Abagirye, who defended the Banyamulenge's cattle against the Simba (Chunguti 2012 int.). Given that the rebels consisted mostly of Babembe and Bafuliiru, the fighting sparked by the counter-insurgency effort assumed the character of inter-community warfare, whereby cattle symbolically marked the fault line. This explains the prominent place that cattle occupy in memories of the Simba war, which is generally identified as the starting point of deteriorating relations between the Banyamulenge and other communities (Vlassenroot 2002). Hence, the violence enacted during the Simba rebellion substantially impacted the later development of communal and cattle-related conflict.

A similar nexus of inter-community tensions and violence would emerge during the First (1996-1997) and Second (1998-2003) Congo Wars, when the Banyamulenge rallied to Rwanda-led insurgencies that were resisted by Bembe, Fuliiru and Vira Mai-Mai groups. Again, cattle symbolically marked the fault lines, and were transformed into 'war resources' as Mai-Mai groups engaged in massive cattle-looting. In September 1998, between 3000 and 4000 cows were stolen in Lulenge by Mai-Mai elements of commander Ngomanya, provoking fierce clashes. A year later, another 3 ooo cows were looted near Kisanga (see Figure 1), close to Minembwe (Chef de secteur Basimunyaka-Sud 2011 int.). In response to this menace, the Banyamulenge suspended transhumance to the distant Ngandja sector of Fizi and solicited protection from troops of the Rassemblement Congolais pour la Démocratie (RCD), the Rwanda-backed insurgency that occupied large parts of the Kivu provinces. This protection arrangement was greatly facilitated by the fact that certain Banyamulenge, including those owning many cattle, held important positions in the RCD's political and military branches, which were present in the Hauts Plateaux. In exchange for sending combatants to guard their cattle during transhumance, representatives of cattleowners would give the RCD commander in Minembwe a financial contribution to pay for soldiers' food and boots (Banyamulenge cattle-owners 2012 int.). This arrangement indicates how during the Congo Wars, armed actors became closely linked to practices related to cattle, whether by being involved in its looting or in the protection against such looting.

While the Second Congo War formally ended in 2003, armed group activity in Fizi and Itombwe continued, like in other areas of the eastern Congo. As part of the peace process, both the RCD and Mai-Mai groups were supposed to integrate their troops into the newly constituted 
national army, the Forces Armées de la République Démocratique du Congo (FARDC). However, many commanders and troops in Fizi and Itombwe refused to integrate, for a variety of reasons. Importantly, the logic of power-sharing created incentives for ongoing mobilisation, as those disappointed with the ranks and positions they had been allocated in the FARDC took up arms to negotiate better terms of integration. Another reason was severe distrust between communities and towards the national army, not believed to be able and willing to protect civilians in case of attacks, including from the numerous foreign rebel groups that continued to roam on Congolese soil (Eriksson Baaz \& Verweijen 2013; Verweijen 2015b). In Fizi and Itombwe, the resulting feelings of insecurity were in part informed by fears for recurrent cattle-looting and transhumance-related conflicts, which mostly centre on devastated fields. These conflicts have not only become more numerous, they have also become more difficult to resolve than before the wars (Brabant \& Nzweve 2013).

The upsurge in violence during the Congo Wars has deteriorated inter-community relations and entrenched mutual distrust between the Banyamulenge and other groups. As a consequence, individual incidents related to transhumance are often seen through the grids of intelligibility of inter-community conflicts, thus inscribing them with wider (symbolic) meanings. In the words of a member of the Cadre de Concertation Intercommunautaire (CCI), a local agropastoral dispute resolution committee:

Cattle herders are too proud, they believe that the farmer is a good-fornothing, a simple slave. Sometimes they even move around without taking the customary chief into consideration. But while the owners of the herds are haughty, the farmers have disdain for the herders. (Secretary of CCI 2012 int.)

As this quote shows, both sides accuse each other of "not wanting to enter into dialogue'. While Babembe and Bafuliiru often accuse the Banyamulenge of being arrogant, framing them as 'Tutsi who feel themselves superior' (Civil society activist 2011 int.), Banyamulenge describe the Babembe and the Bafuliiru as hot-headed and violent, 'directly pulling their machetes' whenever they get into a conflict (Chef de localité of Kakenge 2012 int.).

The salience of narratives of inter-community conflict has also contributed to changes in the meanings and effectiveness of the itulo system, the customary contribution that cattle-keepers pay to the chef de groupement controlling the lands that cattle pass and graze on 
(Brabant \& Nzweve 2013). Customary chiefs of other communities accuse the Banyamulenge of having seized upon the Congo Wars, and the political and military strength they enjoyed during that period, to reduce or stop the payment of itulo, which is also increasingly seen in purely monetary, rather than social, terms. As a chef de groupement testifies:

Before the war, they [Banyamulenge] paid the itulo without any problem; milk, goats, chickens, cows ... But then, because they have become armed, they have wanted to impose themselves. Since 1996, I have not received the itulo anymore. (Chef de groupement of Basimukindje 2011 int.)

While this reading is contested by Banyamulenge cattle-keepers, who generally emphasise that they have continued to pay, it is indicative of how distrust erodes mechanisms of social regulation.

The continuing presence of armed groups recruited from among certain communities strongly perpetuates the mutual distrust between cattle-keepers and farmers, and undermines the effectiveness of conflict-resolution initiatives like the CCI. In particular, it makes each side fear that the other party to the conflict will adopt an intransigent attitude, as they can mobilise armed actors to back up their position, or take recourse to armed force when dissatisfied with the outcome of efforts to settle the dispute. Even when no party has solicited armed actors to intervene, their opponents may still believe this to be the case. For instance, they may suspect that the opposing camp convinced the Mai-Mai to steal cattle in order to take revenge, thereby destroying a previously reached settlement.

Suspicions of armed actor interference in disputes are all the more understandable in the light of the widespread occurrence of this practice throughout the eastern Congo (Eriksson Baaz \& Verweijen 2014). This interference tends to be a two-way street: on the one hand, armed actors impose themselves on all sorts of communal, family and inter-personal conflicts. On the other hand, civilians, including authorities, actively solicit such interventions, in this way trying to reinforce their own power position and settle personal conflicts and scores (Eriksson Baaz \& Verweijen 2014). While the mechanisms channelling these interventions resemble those of Mafia-like protection (Gambetta 1993), they do not always involve monetary compensation. Rather, they may also stem from social relationships that primarily revolve around patronage. Such particularistic protection mechanisms are also mobilised for cattle-related issues. Armed group members may, for instance, intervene in conflicts related to cattle-theft or the 
destruction of agricultural fields, by intimidating herders or farmers believed to have attacked cows. Unsurprisingly, such militarised interventions rarely lead to the 'settlement' of conflicts, as the disadvantaged party tends to contest the legitimacy of the used procedure. By contrast, these practices tend to aggravate conflicts, creating new grievances and feelings of injustice. Additionally, they may prompt the disadvantaged party to solicit protection from armed actors too, creating cycles of revenge actions that may spark wider violence (Eriksson Baaz \& Verweijen 2014). Such violence is only indirectly related to the original conflict around transhumance or stolen cattle, and critically results from the practices of armed actors, rather than those of the (civilian) parties to the conflict alone.

MAI-MAI GROUPS: CATTLE-LOOTING AS AUTODÉFENSE?

For several Mai-Mai groups operating in Fizi and Itombwe, notably the groups of Mulumba, Yakotumba, and previously, Assani Ngungu (2007-2009) and Aoci (2008-2013) (see Figure 1), the stealing and 'taxation' of cattle occupy a prominent place in their repertoires of violence and income generation. During transhumance, combatants of the Mai-Mai Mulumba may show up on the road and demand herders to give them a contribution either in money or in kind, to ensure a safe continuation of their journey. They often call this itulo, thereby appropriating the discourses and authority of customary chiefs. The demanded amounts (usually referring to heads of cattle) depend on the intentions of the Mai-Mai group in question and the outcome of complex negotiation processes, which are strongly shaped by the type and degree of coercion involved. While in some cases Mai-Mai fighters may approach the herder and simply ask for a contribution, in others, they first encircle and capture the herd, making liberation conditional upon payment (Veterinarian of Mutambala sector 2012 int.). It also regularly occurs that Mai-Mai combatants attack herders, killing or torturing them. Another system of wealth extraction employed by Mai-Mai groups is more or less organised 'taxation', whereby herders pay a fixed amount for every head of cattle that traverses the Mai-Mai's area of control. For example, at the start of the transhumance season in 2012, the Mai-Mai Aoci sent a message to cattle-owners that they would need to pay $\$ 4$ for each cow passing their fief (Life \& Peace Institute 2012). Such 'taxes' have also been imposed by the Mai-Mai Mulumba, who tend to erect barriers on the road from Minembwe to Lulenge (see 
Figure 1), but may also collect 'taxes' during visits to villages, forcing cattle-keepers to pay 5ooo Francs congolais (about $\$ 5$ ) each (Civil society activists 2011 int.).

Aside from imposed contributions and 'taxation', Mai-Mai groups sometimes steal cattle. This either takes the form of small-scale theft, which may also be committed by bandits not connected to armed groups, or be massive looting sprees, with hundreds of cows being taken during well-prepared military operations. Attacks on cattle constitute an important source of income for the Mai-Mai. Cows are sold for on average of $\$ 15^{\circ}-5^{\circ o}$, depending on type and quality, which are huge sums for the lower strata of Congolese society. By comparison, the official salary of an FARDC soldier during mid-2014 was approximately $\$ 85$ per month, with officers earning only slightly more (Verweijen 2015b). However, while for certain Mai-Mai groups, such as the Mai-Mai Aoci and Mulumba, revenues from cows appear to constitute a considerable, if not the largest, share of their income, for other groups this is not the case. These groups derive a larger part of their revenues from sources such as imposed contributions in kind (e.g. foodstuffs, goats) on villages, and various 'taxes' and protection fees levied at markets, roads and artisanal mining sites (cf. Van Damme 2012). Some groups, like the Mai-Mai Yakotumba, also receive donations from politicians, like national members of parliament, who sympathise with their cause or hope to gain votes in their sphere of influence, and who are commonly from the same ethnic group as the Mai-Mai leadership (UNSC 2011 ).

In addition to out of monetary interest, Mai-Mai groups also target cattle for symbolic reasons, in this way hoping to rally the popular and elite support that brings resources and recruits, and allows for enhanced social control. These symbolic stakes are reflected in the discursive framings they adopt, which portray cattle-looting as a form of autodéfense (selfdefence) of cultivators against the destruction inflicted by cows, hence a legitimate form of violent action to defend the rights of cultivators. In the words of a member of the Mai-Mai Mulumba:

There where the Bafuliiru cultivate, the Banyamulenge send their cows. When the Bafuliiru have cows, they guard them well and they rapidly apologise when there are problems in relation to a field. But the Banyamulenge, they do not want to indemnify the destructions caused by their cows. This is why the Bafuliiru have said: 'If you do not want to guard your cows well, we will revolt' ... Mulumba still refuses that the cows of the Banyamulenge arrive in his fief and destroy the fields: the Mai-Mai Mulumba defend the cultivators. (Spokesperson Mai-Mai Mulumba 2012 int.) 
Mai-Mai groups may also present cattle-looting as an attack on the Banyamulenge/Tutsi community and its putative expansionist tendencies, hence a form of autodéfense of 'autochthones' against 'invading foreigners' and their ambitions to grab their ancestral lands. Such 'invasions' are sometimes also associated with transhumance, with cattle being imagined as a 'vanguard' occupying autochthones' lands. Framing transhumance in such terms not only reflects the Mai-Mai's worldviews, but also allows them to capitalise upon existing frustrations among cultivators about this practice (Brabant \& Nzweve 2013).

However, not all farmers support the Mai-Mai. The attitudes of the population towards these groups are heterogeneous, ambiguous and fluctuating (Verweijen 2015a), and the same applies to their engagement in cattle-looting. The spoils of large-scale cattle-looting are generally not shared with the ordinary farmer, who also tends to heavily suffer from the resulting tensions and insecurity. It is therefore not surprising that farmers often state to regret such acts, fearing revenge actions from the side of the Banyamulenge (Representatives local community organisations 2010 and 2011 int.). Paradoxically, it is these very feelings of insecurity and fears for revenge that foster a certain support for MaiMai groups, especially in the absence of national armed forces perceived as willing and capable to protect the population.

Although farmers may have mixed feelings about cattle-looting by the Mai-Mai, those whose cows are targeted - primarily the Banyamulenge often do not perceive this ambivalence. Instead, they tend to assume that cattle-looting reflects the will of the communities out of whose midst Mai-Mai groups are recruited. Mai-Mai groups are commonly described as batoto or 'the children' of a certain community, which suggests a close link. As a result, cattle-looting is seen as an attack by an entire community on another community. Due to the violent history of inter-community relations in this part of South Kivu, which resonates with the wider history of anti-Tutsi violence in the Great Lakes Region, including the Rwandan genocide, the Banyamulenge readily regard such attacks as an existential threat. As a Munyamulenge elder commented: 'They [Mai Mai] are all the same. We will never trust them as we know what they have done to us during the war' (Village elder 2011 int.). This perception explains why Banyamulenge armed groups may respond fiercely to cattle-looting, experiencing an immediate need to defend their own community, and discursively presenting their actions accordingly. Consequently, Babembe and Bafuliiru often consider the practices of Banyamulenge rebel groups like the FRF to express the will of the Banyamulenge community, including when it concerns attacks on 
their villages. However, here too, the relations between communities and armed actors are more complex than dominant narratives assume, and many Banyamulenge in fact do not approve of such attacks.

BANYAMULENGE FORCES: PROVIDING 'PROTECTION'?

After the adoption of the final peace accord in 2003, the main military force on the Hauts Plateaux of Fizi and Itombwe was the troops of Pacifique Masunzu, a Munyamulenge commander who had revolted against the RCD and the Rwandan army during the Second Congo War. This unit, which was eventually transformed into the 112 th brigade FARDC, was not eager to participate in the army integration process, in large part because Masunzu wanted to hold on to his power position on the Plateaux. Masunzu felt particularly threatened by two dissident Banyamulenge factions (led by Venant Bisogo and Michel 'Makanika' Rukunda) that emerged in the course of 2005, and that merged in 2007 to form the rebel group FRF (Verweijen \& Vlassenroot 2015). The continuing presence of non-integrated MaiMai forces, including those responsible for massive cattle-looting, further reduced Masunzu's enthusiasm for mixing his troops with the national army. Despite serious fighting, Masunzu's brigade, which firmly controlled the Minembwe area, could not prevent the FRF from consolidating its hold over the Mibunda and Kamombo areas of the Plateaux (see Figure 1). Becoming the de facto governors of that zone, the rebels developed considerable popularity among the Banyamulenge population there, in part as the latter felt that they and their cattle were now better protected against the Mai-Mai (Village elders 2010 and 2011 int).

Indeed, the FRF generally tried to defend the Banyamulenge and their property against the Mai-Mai, whom they portrayed as purely criminal bands, whose main activity is to steal cows. For example, the supreme commander of the FRF, Michel 'Makanika' Rukunda, stated: 'For us, the Aoci are just armed robbers' (Makanika 2010 int.). However, by ascribing the Mai-Mai purely economic motives, they downplayed that these groups also expressed grievances that were widely felt among the non-Banyamulenge population of the Plateaux. In particular, the Babembe in Itombwe felt threatened by the hegemony of the allBanyamulenge FRF and their demands to re-erect a separate administrative unit carved out of the customary territory of other communities (namely, Minembwe territory), which had briefly existed under the 
RCD administration during the Second Congo War (Verweijen \& Vlassenroot 2015).

The mutual distrust between Babembe and Banyamulenge, and the general identification of the Mai-Mai Aoci and the FRF with these respective communities, caused individual acts of cattle-looting to often provoke chains of reactions that spiralled out of control. In August 2009, the Mai-Mai Aoci stole hundreds of heads of cattle in the Mibunda area of Itombwe, which provoked a counter-offensive by the FRF in Kabandja, allowing them to liberate a substantial amount of stolen cows. However, the FRF's intervention sharpened inter-communal tensions, which sparked heavy fighting in the village of Kipombo, drawing in demobilised Banyamulenge and Mai-Mai fighters from the Second Congo War and other inhabitants. In 2010, the MaiMai Aoci again managed to steal hundreds of cows in the Mibunda area, which nourished further antagonism among the Banyamulenge towards the Babembe, who were blamed for Aoci's behaviour. This climate of antagonism partly explains why an assassination at the end of 2011 in Tulambo, which stemmed from a commercial dispute around gold mining interests, was nevertheless interpreted in the light of inter-community tensions, and provoked the cycle of tit-for-tat killings that prevented the elections from taking place in Itombwe, as described at the start of this article.

A similar complex interplay between worsening inter-community relations, cattle-looting and armed group activity had occurred in the course of 2008 in the Minembwe area, after the Mai-Mai Mulumba and the MaiMai Assani Ngungu looted dozens of cows near Kitumba (see Figure 1). Discontent with the performance of the 112 th brigade FARDC controlled by Masunzu, cattle-owners supported a counter-attack conducted by an armed group consisting of demobilised fighters and young Banyamulenge, which operated under the name Twigwaneho, Kinyamulenge (the Kinyarwanda dialect spoken by the Banyamulenge) for 'Let's defend ourselves'. Also described as the 'Mai-Mai of the Banyamulenge', this group surfaces in times of (perceived) need, sometimes in an ad-hoc manner, and places itself in the tradition of the Abagirye operating during the Simba rebellion (Brabant \& Nzweve 2013). It was also the latter's former commander Chunguti, active as a protestant army chaplain for the FARDC in Minembwe, who took the initiative to mobilise the Twigwaneho in 2008. The justificatory and mobilising discourses employed by this militia mirror those of the Mai-Mai both in their emphasis on autodéfense and the invocation of supposedly antagonistic ethnic groups as the main source of threat, thereby 
stigmatising communities as a whole. As the Twigwaneho's main commander, Raban Musemakweli Senga, explains:

The Twigwaneho are there and remain a movement to defend the property of the Banyamulenge. Because even when they promise us reconciliation, it will always be the same: the Babembe will come after two days to pillage our cows. This is why, in every place where there are villages inhabited by the Banyamulenge, I have deployed youth that is part of the Twigwaneho. (Musemakweli 2012 int.)

The Twigwaneho, which started to wane in 2010, played an important role in securing cattle, not only by patrolling near grazing grounds, but also by accompanying cows during transhumance. Furthermore, they were deployed for counter-attacks in case of Mai-Mai assaults, and to trace back the stolen cows. The Twigwaneho, however, were not universally supported among the Banyamulenge. Some believed that this initiative only provoked further inter-community tensions, preferring non-violent responses to cattle-looting (Notables 2012 int.). Others were of the opinion that the Twigwaneho undermined the work of the state security services, setting a precedent whereby all groups mobilise according to their own insights and interests (School teachers 2010 int.). Yet, the security services are widely regarded not only as incapable of protecting lives and property, but also unwilling, due to a lack of neutrality. These perceptions, and the practices of the national armed forces that feed them, are a crucial factor in the nexus between cattlerelated and inter-community conflicts and armed mobilisation and violence.

THE EFFECTS OF A NON-NEUTRAL ARMY

Personnel from the FARDC, in particular officers, are both directly and indirectly involved in cattle-related affairs. FARDC officers of units deployed to Fizi and Itombwe often intervene in conflicts related to cattle-theft or the destruction of agricultural fields, for example arresting suspected thieves or local authorities such as the kapita (village chief), held responsible for the acts of their villagers. FARDC personnel may also be deployed to track down stolen cattle, or attack Mai-Mai groups that launched cattle raids (Civil society activists 2012 int.). Additionally, they sometimes protect cows during transhumance, commonly due to protection relations with the owners, whether on a purely monetary basis or in the framework of patronage. It sometimes even occurs that cattle owners give a cow directly to FARDC 
commanders instead of paying itulo to customary chiefs (Community organisation member 2012 int.). Such private deals strongly undermine the perceived neutrality of the military, especially as these interventions tend to benefit cattle-owners.

There are a number of reasons why the practices of the FARDC are often skewed towards the interests of cattle-owners. First, the latter have cows to offer, and therefore have an advantage in terms of courting the FARDC. Furthermore, in particular up to 2015, many Banyamulenge owning cattle had relatives in the FARDC units that were deployed in Fizi and Itombwe, who often intervened to protect their cattle. These units were dominated by Banyamulenge troops from both the 112th brigade and, after 2011, the (former) FRF, which laid down their arms and integrated into the FARDC in January that year. Additionally, there are many high-ranking Banyamulenge officers in the provincial and national military hierarchy who have cattle in the area, like General Masunzu, the former commander of the 1oth Military Region. These powerful officers commonly manipulate locally deployed FARDC commanders to ensure the protection of their cattle (Human rights defenders 2012 and 2014 int.). It appears, however, that not only Banyamulenge, but also other Rwandophone officers (both Tutsi and Hutu), often from North Kivu, enter into protection arrangements with cattle-owners. While this is primarily related to monetary incentives, the fact that they speak the same language and share a high appreciation for cows, as is characteristic for Kinyarwanda speaking groups, may facilitate developing relations.

Even where such close linkages between Rwandophone commanders and cattle-owners do not materialise, they are assumed to exist by selfstyled autochthonous groups, due to their tendency to lump all different Kinyarwanda speaking groups together in the undifferentiated category of Rwandophones. It is a hallmark of autochthony discourses that they revolve around a flexibly defined dichotomy between insiders and outsiders, implying that the boundaries around the category of 'the Other' are constantly redrawn, according to situational dynamics (Jackson 2006). Such boundary-redrawing, for instance to equate local (Tutsi) Banyamulenge in Fizi with Hutu FARDC officers from North Kivu, partly stems from the discursive practices of politico-military entrepreneurs. This primarily concerns Mai-Mai groups and their political supporters, including local authorities and politicians, who play an important role in sustaining these groups. By portraying the army as 'dominated by' and 'biased towards' Rwandophones, these violent entrepreneurs provide a raison d'être for Mai-Mai groups, allowing them to 
frame their (violent) activities as 'legitimate autodéfense' against the Banyamulenge's putative plan to forcibly occupy their lands (Verweijen 2015a). That such frames find 'resonance' among broad layers of the population is a result not only of a long history of inter-community tensions, but also of negative experiences with Rwandophone troops. Due to the atrocities committed by Rwandophone-commanded armed forces during the Congo Wars, many people in the Fizi and Itombwe area have bad memories of Rwandophone soldiers. This affects perceptions of current troops, as reflected in the often-voiced expression muguu ilioumwa na nyoka ugopa muzuzi ("the leg that has been bitten by a snake will fear the lizard'). Distrust is further reinforced by contemporary negative experiences with the armed forces stemming from their penchant for abusive practices, which is not limited to the Rwandophone components (Verweijen 2015b).

The Banyamulenge, for their part, also have limited trust in the FARDC, fearing in particular ex-Mai-Mai commanders. Reflecting similar framing mechanisms as those underlying the autochthony discourse, in particular the tendency to lump together diverse groups in homogeneous categories, this distrust does not only relate to ex-MaiMai from Fizi and Itombwe, but also applies to former Mai-Mai from other areas of the eastern Congo, who are suspected to maintain links with local Mai-Mai groups. For instance, one reason why the FARDC could do little to stem the violence in the Itombwe area during the electoral period in 2011 was that the battalion commander, an ex-Mai-Mai from Walikale (North Kivu), was rumoured to have provided arms and ammunitions to the Bembe Mai-Mai of Aoci (Village chiefs and elders 2011 int.). Such framings do not emerge spontaneously but are actively propagated by those who stand to gain from them, often local authorities and politicians sympathising with armed groups. Furthermore, these narratives find popular resonance as they speak to a long history of negative experiences with armed bands from self-styled autochthonous communities, who engaged in ethnically targeted harassment and massacres of Banyamulenge on the eve of and during the Congo Wars (Verweijen $2015 \mathrm{~b})$.

As the above discussion shows, limited confidence in the neutrality of the FARDC enhances the impulse to support armed groups in times of insecurity and inter-community tensions, even when people do not fully agree with these groups' agenda or practices. Armed groups are seen to offer a last line of defence, constituting a counter-weight to an abusive army or compensating for its deficient security performance. However, since most armed groups are recruited from and seen as emanations 
of particular communities, this self-defence mechanism has detrimental effects on inter-community conflicts. Moreover and paradoxically, the insecurity that is created by armed groups is one of the main drivers of popular support for these groups. Similar counterproductive effects are generated by protection arrangements with members of the national armed forces; born from the need to shield oneself and one's property against insecurity, protection mechanisms undermine the perceived neutrality of the armed forces, therefore feeding into dynamics of autodéfense that end up creating more insecurity. Within these various self-enforcing cycles of insecurity, the national army plays a crucial role, mediating the interplay between local conflicts and armed mobilisation.

\section{O N C L U D I G R E M A R K S}

Analysing the interplay of cattle-related conflicts and armed mobilisation and violence in the Fizi and Itombwe region in South Kivu, this article has shown how such conflicts are impacted by both past violence and the present-day activities of armed groups and the national army. Due to mutual distrust between communities stemming from a long history of tensions and occasional violence, as well as from the contemporary activism of politico-military entrepreneurs, individual incidents surrounding transhumance or cattle theft become perceived through the lens of wider inter-community frictions. Furthermore, given the imagined blurred boundaries between communities on the one hand, and armed groups and army factions on the other, it is feared that parties to a conflict solicit protection from armed actors to reinforce their positions. As a consequence, existing mechanisms of conflict regulation have become eroded, which in turn increases incentives to indeed solicit armed actors to 'settle' disputes. While agropastoral conflicts are thus influenced by armed mobilisation, these conflicts in turn influence such mobilisation. One way in which this occurs is that conflicts provide grids of intelligibility and narrative frameworks on which politico-military entrepreneurs can draw to frame and justify their activities. Crucially, these narratives allow them to portray their (violent) practices as the legitimate defence of the rights of either cultivators or cattleowners and their property. Moreover, they enable politico-military entrepreneurs to employ stereotypes to provide simple explanations for complex social phenomena that 'resonate' among their supporters. 
In this way, these narrative frameworks and corresponding justifications facilitate the mobilisation of recruits and resources.

Our analysis thus demonstrates that the links between cattle-related conflicts and violence are often more indirect than direct. In many cases, violence is neither directly related to the destruction of fields nor primarily enacted by duped farmers or herders. Rather, it mostly takes the form of clashes and revenge actions resulting from cattlelooting by Mai-Mai groups and counter-mobilisation by other armed groups or the government forces. Although armed groups are commonly formed on a mono-ethnic basis and claim to represent the interests of the communities they issue out of, they clearly also have divergent interests and agendas, related to the ambitions of their leadership and political supporters. Additionally, while mobilisation to attack or defend cows is often framed as necessary and justified to protect the community, these framings are manipulated by politico-military entrepreneurs, and therefore do not always reflect the views of communities as a whole. Furthermore, discourses on the necessity of armed mobilisation for reasons of self-defence are lent crucial credibility by the meagre security performance and perceived lack of neutrality of the Congolese armed forces.

By highlighting the complexity of the links between agropastoral conflicts and violence, and by detailing the involved causal mechanisms, this paper contributes to the debates on violent herder-farmer conflicts. In particular, it shows how wider conflict narratives, which are rendered salient through the social and discursive practices of both politico-military entrepreneurs and the government armed forces, are essential for transforming individual instances of cattle-related conflict or crime into wider frictions that may become militarised. Notably, these narratives contribute to legitimising violent practices, like cattle-looting, even when these practices are not directly related to the conflicts that are invoked. As such, our findings emphasise the need to disaggregate different types of conflict (e.g. interpersonal, communal) and different types of violence and violent actors (e.g. cattle theft by thieves, cattlelooting by Mai-Mai groups, revenge practices by army soldiers charged with protecting cattle), and to detail the interaction between these various factors and actors, in terms of both discursive and social practices. Such an approach promises to significantly advance the study of agropastoral conflicts in violent settings.

At the same time, our analysis refines theories that emphasise the role of local conflicts in the ongoing violence in the eastern Congo. For Autesserre, 'grassroots rivalries over land, resources, and political 
power' (2010:42) are a driving force of what she terms 'local violence'. This paper elaborates upon this analysis by detailing the causal mechanisms and processes by which local conflicts contribute to violence. As we have showed, armed groups play a crucial role in this process, but neither their presence nor their violent practices are uniquely or directly the result of local conflicts. Rather, their activities are also the product of the interests and visions of politico-military entrepreneurs, who are connected to and draw upon supra-local networks and discourses. Furthermore, armed mobilisation is strongly shaped by the perceived lack of neutrality and capabilities of the national armed forces as well the tendency of officers to engage in private protection arrangements. In sum, the links between local conflicts and violence play out in more indirect manners and involve more supra-local factors than theories emphasising the role of 'the local' seem to suggest. Furthermore, the link between local conflicts and armed violence is not unidirectional, but mutual: the presence of armed groups and the occurrence of violence crucially alter the nature of conflicts, as they transform their stakes and erode mechanisms of social regulation, which contributes to these conflicts' militarisation. Again, supra-local actors and discourses play important mediating roles in generating these effects.

By drawing attention to the pertinence of supra-local processes in the ways in which local conflicts contribute to violence, our analysis contributes to a growing body of literature that highlights the inadequacies of theories on violent conflict and peacebuilding that draw on reified interpretations of 'the local', arguing that rather than as a (spatially) fixed arena, it should be conceptualised as a shifting node in wider social networks and processes (Hirblinger \& Simons 2015; Mac Ginty 2015 ). But a nuanced grasp of the links between local conflicts and violence is not only of theoretical interest, it is also crucial for understanding the intractability of violent conflict in the eastern Congo. In particular, it explains why relatively mundane conflicts or instances of minor crime, like the stealing of one cow, feed into wider cycles of conflict and insecurity that importantly sustain armed groups. These effects stem from both the discursive frameworks that these groups and their political supporters draw upon, which provide meaning to individual disputes and these groups' own activities, and the feelings of insecurity that result from the employed conflict narratives and from armed group presence. Paradoxically, the responses that people develop to cope with this insecurity, such as protection arrangements with members of the armed forces and the formation of self-defence groups, only further undermine the possibilities to resolve conflicts in 
a non-violent manner, and often become new sources of insecurity. One reason for this is that such responses tend to (re)confirm the validity of the conflict narratives that politico-military entrepreneurs actively (re) produce, 'proving' the unreliability of the army and the hostility of 'enemy' communities. These narrative frameworks thus become selffulfilling prophecies, with each mundane conflict or each intervention by armed actors being seen through the related grids of intelligibility, therefore becoming new forms of justification for armed group activity and army manipulation. In this manner, the continually interacting dynamics of conflict, armed mobilisation and violence in the eastern Congo seem to have almost become a perpetuum mobile.

\section{N O T E}

1. Although we are aware of the problematic connotations and reifying effects of the term 'community' (Joseph 2002), we employ it nonetheless, in part as it is widely used in the research context (as communautés), hence concerns an emic concept that captures modes of reasoning that are crucial for understanding the social phenomena described herein.

\section{R E F E R E N C E S}

Abbink, J. 1998. 'Ritual and political forms of violent practice among the Suri of southern Ethiopia', Cahiers d'Études Africaines 38: 271-95.

Abrahams, R. 1987. 'Sungusungu: village vigilante groups in Tanzania', African Affairs 86: 179-96.

Van Acker, F. 2005. 'Where did all the land go? Enclosure \& social struggle in Kivu (DR Congo)', Review of African Political Economy 32: 79-98.

Agade Mkutu, K. 2008. Guns and Governance in the Rift Valley: pastoralist conflict and small arms. Bloomington, IN: Indiana University Press.

Autesserre, S. 2010. The Trouble with the Congo: local violence and the failure of international peacebuilding. Cambridge: Cambridge University Press.

Benjaminsen, T.A., F.P. Maganga \& J.M. Abdallah. 2009. 'The Kilosa killings: political ecology of a farmer-herder conflict in Tanzania', Development and Change $40: 423-45$.

Beyene, F. 2009. 'Property rights conflict, customary institutions and the state: the case of agro-pastoralists in Mieso district, eastern Ethiopia', Journal of Modern African Studies 47: 213-39.

Bogale, A. \& B. Korf. 2007. 'To share or not to share? (Non-) violence, scarcity and resource access in Somali region, Ethiopia', Journal of Development Studies 43: 743-65.

Brabant, J. \& J.-L. Nzweve. 2013. La Houe, la Vache et le Fusil. Conflits liés à la transhumance en territoires de Fizi et Uvira (Sud-Kivu, RDC). Uppsala: Life \& Peace Institute.

Breusers, M., S. Nederlof \& T. Van Rheenen. 1998. 'Conflict or symbiosis? Disentangling farmerherdsman relations: The Mossi and Fulbe of the Central Plateau, Burkina Faso', Journal of Modern African Studies 36: 357-80.

Brubaker, R. \& D. Laitin. 1998. 'Ethnic and nationalist violence', Annual Review of Sociology 24: 423$5^{2}$.

Collins, R. 20o8. Violence: a micro-sociological theory. Princeton, NJ: Princeton University Press.

Van Damme, S. 2012. 'Commodities of war. Communities speak out on the true cost of conflict in eastern DRC'. London: Oxfam International.

Depelchin, J. 1974. 'From pre-capitalism to imperialism: a history of social and economic formations in eastern Zaire (Uvira zone, c. $1800-1965$ )'. Stanford University, PhD. dissertation.

Eaton, D. 2008. 'The business of peace: raiding and peace work along the Kenya-Uganda border (Part I)', African Affairs 107: 89-110. 
Eriksson Baaz, M. \& J. Verweijen. 2013. 'The volatility of a half-cooked bouillabaisse. Rebel-military integration and conflict dynamics in eastern DRC', African Affairs 1 1 2: $563-82$.

Eriksson Baaz, M. \& J. Verweijen. 2014. 'Arbiters with guns: the ambiguity of military involvement in civilian disputes in the DR Congo', Third World Quarterly 35: 803-20.

Fleisher, M.L. 2002. "War is good for thieving!" The symbiosis of crime and warfare among the Kuria of Tanzania', Africa 72: 131-49.

Gambetta, D. 1993. The Sicilian Mafia: the business of private protection. Cambridge, MA: Harvard University Press.

Greiner, C. 2013. 'Guns, land, and votes: cattle rustling and the politics of boundary (re)making in Northern Kenya', African Affairs 112, 447: 216-37.

Hagmann, T. 2005. 'Confronting the concept of environmentally induced conflict', Peace, Conflict and Development 6: 1-22.

Hagmann, T. \& A. Mulugeta, 2008. 'Pastoral conflicts and state-building in the Ethiopian lowlands', Africa Spectrum 43: 19-37.

Harshbarger, C.L. 1995. 'Farmer-herder conflict and state legitimacy in Cameroon'. University of Florida, PhD dissertation.

Hendrickson, D., R. Mears \& J. Armon. 1996. 'Livestock raiding among the pastoral Turkana of Kenya: redistribution, predation and the links to famine', IDS Bulletin 27: 17-30.

Hirblinger, A.T. \& C. Simons. 2015. 'The good, the bad, and the powerful: representations of the local in peacebuilding', Security Dialogue 46: 422-39.

Homer-Dixon, T.F. 1999. Environment, Scarcity, and Violence. Princeton, NJ: Princeton University Press.

Hughes, C., J. Öjendal \& I. Schierenbeck. 2015. 'The struggle versus the song-the local turn in peacebuilding: an introduction', Third World Quarterly 36: 81 7-24.

Hundie, B. 2010. 'Conflicts between Afar pastoralists and their neighbors: triggers and motivations', International Journal of Conflict and Violence 4: 134-48.

Hussein, K., J. Sumberg \& D. Seddon. 1999. 'Increasing violent conflict between herders and farmers in Africa: claims and evidence', Development Policy Review 1 7: 397-418.

Jackson, S. 2006. 'Sons of which soil? The language and politics of autochthony in eastern DR Congo', African Studies Review 49: 95-124.

Joseph, M. 2002. Against the Romance of Community. Minneapolis, MN: University of Minnesota Press.

Krätli, S. \& J. Swift. 1999. 'Understanding and managing pastoral conflict in Kenya: a literature review'. Institute of Development Studies, University of Essex.

Life \& Peace Institute. 201 2. 'Rapport de mission à Minembwe, Uvira et Baraka', 25.6.201 2 (unpublished document).

Mac Ginty, R. 2015. 'Where is the local? Critical localism and peacebuilding', Third World Quarterly $3^{6:} 84^{\mathrm{O}-} 5^{6 .}$

Markakis, J. 1997. Resource Conflict in the Horn of Africa. London: Sage.

Mirzeler, M. \& C. Young, 200o. 'Pastoral politics in the northeast periphery in Uganda: AK-47 as change agent', Journal of Modern African Studies 38: 407-29.

Muchukiwa, B. 2006. Territoires Ethniques et Territoires Étatiques: pouvoirs locaux et conflits interethniques au Sud-Kivu (RD Congo). Paris: L'Harmattan.

Mwaura, C. \& S. Schmeidl. 2002. Early Warning and Conflict Management in the Horn of Africa. Lawrenceville, NJ: Red Sea Press.

Odhiambo, M. 2004. 'Karamoja conflict study: a report'. London: Oxfam International.

Pelican, M. 2009. 'Complexities of indigeneity and autochthony: an African example', American Ethnologist 3 6: $5^{2-65}$.

Rukundwa, L. S. 2006. 'Justice and righteousness in Matthean theology and its relevance to the Banyamulenge community: a postcolonial reading'. University of Pretoria, PhD dissertation.

Tonah, S. 2003. 'Integration or exclusion of Fulbe pastoralists in West Africa: a comparative analysis of interethnic relations, state and local policies in Ghana and Côte d'Ivoire', Journal of Modern African Studies 41: 91-114.

Umar, A.N. 1997. 'Resource utilisation, conflict and insecurity in pastoral areas of Kenya'. Nairobi: Kenya Pastoral Forum.

UNSC (United Nations Security Council). 2011. Final Report of the Group of Experts on the Democratic Republic of the Congo. S/2011/738. New York: UNSC.

Verhaegen, B. 1966. Rébellions au Congo Vol. 2. Brussels: CRISP.

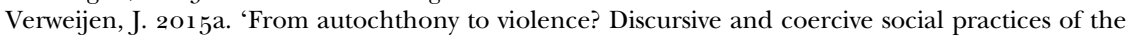
Mai-Mai in Fizi, eastern DR Congo', African Studies Review 58: ${ }_{57}-80$. 
Verweijen, J. 2015 b. 'The ambiguity of militarization. The complex interaction between the Congolese armed forces and civilians in the Kivu provinces, eastern DR Congo'. Utrecht University, $\mathrm{PhD}$ dissertation.

Verweijen, J. \& K. Vlassenroot. 2015. 'Armed mobilisation and the nexus of territory, identity, and authority: the contested territorial aspirations of the Banyamulenge in eastern DR Congo', Journal of Contemporary African Studies 33: 191-212.

Vlassenroot, K. 2002. 'Citizenship, identity formation \& conflict in South Kivu: the case of the Banyamulenge', Review of African Political Economy 29: 499-516.

\section{Interviews}

Banyamulenge cattle-owners, Rugezi, 4.4.2012.

Chef de groupement of Basimukindje, Baraka, 16.2.2012.

Chef de localité of Kakenge, Minembwe, 2.4.2012.

Chef de secteur, Basimunyaka-Sud, Fizi centre, 30.1 2.2011.

Chief of Basimunyaka clan, Baraka, 16.6.2012.

Chunguti, Jérôme, former Abagiriye chief, Minembwe, 1.4.2012.

Civil society activist, Kilembwe, 25.12.2011.

Civil society activists, Kagembe, $24 \& 25.12 .2011$ and Minembwe, 6 \& 7.12.2011.

Civil society activists, Lulimba, 18.12 .2012 .

Community organisation member, Baraka, 2.5.2012.

Human rights defenders, Uvira, 28.2.2012 and 27.6.2014.

Michel 'Makanika' Rukunda, FRF leader, Kabara, 22.12.2010.

Musemakweli Raban, Bukavu, 2.3.2012.

Notables, Rugezi, 3.4.201 2.

President of cattle-herders, Bibokoboko, 22.7.2012.

Representatives local community organisations, Mibunda 15.12.2010, Lulimba, 21.12.2011 and Kilembwe, 24.12.2011.

School teachers, Minembwe, 26.12.2010.

Secretary of CCI (Cadre de Concertation Intercommunautaire), Baraka, 23.2.201 2.

Spokesperson of Mai-Mai Mulumba, Uvira, 23.6.2012.

Veterinarian of Mutambala sector, Baraka, 15.6 .2012$.

Village chiefs and elders, Kamombo, 26.11. 2011 and Mikenke, 28.11.2011.

Village elder, Marunde, 28.11.2011.

Village elders, Mibunda, 14.12.2010, Kamombo and Kabare, 22.12.2010, Mikalati 29.1.2011. 